\title{
The Attribute of Compatibility between the Process of Organization and the Function of Human Resources
}

\author{
Mihai Varzaruํ․ Ion Stancu², Anca Antoaneta Varzaru ${ }^{3}$
}

\begin{abstract}
:
The evolution of the organizational forms has seen quite dynamic in recent years, registered trends being observed in the enterprise subsystems. The human resources function, a subsystem in continuous development since the 1990s, is subjected to changes such as decentralization, hierarchical reduction and resizing, as a consequence of its missions delegation both inside and outside the organization. Approach: These changes are exacerbated by the emergence of new techniques of information and communication (NTIC), which change the context in which human resources function evolves. The need to adapt the development of human resources function to the enterprises' strategy causes a strategic alignment requirement. Results: The functions' content will also be modified, in the direction of what may designate e-Human Resources, characterized by the increasing role of the Intranet, the use of the NTIC in supporting activities such as e-recruiting and e-learning. Conclusion/Recommendations: The article highlights the need for consistency between the process of organization and the function of human resources, the necessary compatibility in the sense that it is not possible to examine the evolution of an enterprise independent of the characteristics of the enterprises the organization is part of.
\end{abstract}

\section{Key Words:}

New Organizational Forms, E-Management, New Techniques of Information and Communication, Compatibility, Human Resources Function

JEL Classification: D21, D22, D24, L22, O15

\footnotetext{
${ }^{1}$ University of Craiova, Faculty of Economics and Business Administration, Craiova, Romania

${ }^{2}$ University of Craiova, Faculty of Economics and Business Administration, Craiova, Romania

${ }^{3}$ University of Craiova, Faculty of Economics and Business Administration, Craiova, Romania,

e-mail: Vărzaru varzaruanca@yahoo.com
} 


\section{Introduction}

The degree of compatibility and correspondence between the internal characteristics of the organization, way of operation, and type of environment the organization faces allow a configuration of a specific manner. This combination will inevitably influence the choices of the organization in matter of management, as previously interested several researchers in organizational design (Perrow,1961; Etzioni,1971; Mintzberg,1986 - a rational perspective; Weick, 1973; Woodward,1965; Burns and Stalker, 1961, Lawrence and Lorsch, 1989; Galbraith, 1973 - contingency perspective; Mintzberg, 1982, 1986; Lawrence and Lorsch, 1989; Giddens, 1979; Pettigrew, 1985, 1987; Nizet and Pichault, 2000; Crozier, 1971 with the political perspective).

In most cases, the types exposed by the researchers are found only partially in reality, they represent marks according to which the organization is placed, according to the models issued by different participants. It is important that they allow managers to be positioned thanks to these models proposed by different authors. However, these models of configuration described do not stand for long, and then they should be updated.

The definition of organizational configuration given by Paillot emphasizes the need for enterprises to take account of multiple internal and external elements in their approach to effectively structure; it also states the fact that existing typologies are found only partially in reality, because they are only the main features of that reality.

The operational design of enterprise depends on two important restrictions:

- internal constraints, developed by Mintzberg (2004), who wants to answer the question of how to organize enterprises;

- external constraints highlighted by Porter and Millar (1985), related to how enterprises are positioned.

Mintzberg (2004) undertakes the largest and most important synthesis ever made in scientific literature on the organizational phenomenon. As a result of intense research and synthesis, Mintzberg (2004) identifies various organizational configurations that can coexist with dynamic and its' transformations, configurations that organizations are facing along their evolution, such as the simple structure, mechanistic bureaucracy, professional bureaucracy, divisional structure and adhocracy. For Mintzberg (2004), the organization's structures may be included in one of the five basic categories listed above. He admits there are two types of adhocracy: operational adhocracy (one unit of creation that evolves in a competitive market, such as an advertising agency or a producer of software) and administrative adhocracy (where work can be directed toward research, for example NASA). 
Regarding their evolution, Mintzberg (1993) mentions that the models of simple structure and mechanistic bureaucracy correspond to the past; professional bureaucracy and divisional structure are specific for today, while adhocracy represents the structure of tomorrow. Aware of continuous change context in which organizations evolves, Mintzberg (1993) does not eliminate the perspective of further development of the structure according to different influences, already announcing two structural configurations: the missionary structure and political structure. The two types occur after a thorough analysis of one of the contingency factors, respectively the power.

The above thematic approach allows the release of a central thesis, highlighting that any organization can be analyzed as a form more or less precise for these different poles, in other words, and any concrete organizational form would necessarily be situated within these configurations. Political organization is characterized by the development of "illegitimate" power. When the enterprise is not able to install a stable system of authority, without a prevailing characteristic, conflicts evolve and get out of control, reaching the form of political enterprise, where each pursues its own interests. Some enterprises are just temporary policy, especially in difficult periods of transformation; others remain like this for long periods of time. The missionary organization is characterized by the harmony of veils and the beliefs of its members, which pays attention not only to internal powers, but also to common interests.

Each person can have a degree of latitude in the organization to which it belongs, indicating an almost pure form of decentralization. To understand the manner in which enterprises formulate their strategy, Mintzberg (1993) is, thus, highly interested and he studies:

The manner, in which the enterprise is structured, as the structure is the basis for numerous organizational problems, factors of contingency, goals and authority system.

Depending on the crucial variables - the conception of the structure, factors of contingency, goals and authority, the author defines five configurations. Each enterprise represents such a structure or a combination of them, being hybrid from this regard. During his research, Mintzberg (1993) calls the rationalist theory, contingency and policy theory.

Actors build organizational context and then these structures are, in turn, restrictions on their action. The second restriction in terms of structural configuration was developed by Porter and Millar (1985), who transferred discussions about 
enterprises' strategy to the marketplace, moving away from the idea of a theoretical concept that applies to different functions of organizations.

He also identifies the five factors that govern the competition and which are very useful to managers who try to analyze the conventional situation of their company:

- $\quad$ rivalry between enterprises;

- threatening of new market entrants;

- the threat of substitute products and services;

- the bargaining power of suppliers;

- the bargaining power of customers.

These factors should be identified as clear, in order to define the best strategy to be adopted, and, where possible, monitored their evolution. Based on these benchmarks, Porter and Millar (1985) define five generic types of enterprise or structural environments: dispersed, to come, maturity, decline and international scale. In terms of competitive advantage, the author considers that a company can have two types, through cost or differentiation. To estimate competitive position, Porter and Millar (1985) use the method "value channel", which explores all the activities and their interactions, reveals the origin and influence costs, existing and potential sources of differentiation.

Channel value theory provides a framework for strategic analysis of the enterprises' activities and the cost evaluation for each of them, and allows knowing the use of a possible differentiation among various activities. The profit of a company corresponds to the gap between the value of its activities and their cost, while the notion of value channel allows rigorous analysis of what is valuable for the buyer and makes him agree to pay a higher price than normal or even abandon a product or service in favor of another.

An enterprise strategy corresponds to a consistent configuration of its activities, which will allow a differentiation over competitors. Porter and Millar (1985) show how the concept of valuable channel can serve as a privileged instrument to diagnose the competitive advantage. He describes the manner to decompose the enterprises' activities that are prior for this advantage and identifies the connections between them.

Porter and Millar (1985) suggest a valuable channel that takes into account new techniques of information and communication (NTIC), which also make Roux and Soulier (1997). The introduction and development of NTIC contribute to the changing of the value creation process, to reduce restrictions regarding the location, geographic position and transformation of the relationships with customers and suppliers. 


\section{New Organisational Forms}

Traditional forms of organization are based on a distribution of tasks and objectives, generating the notion of hierarchy and a report type of activity designed to ensure the systems' balance. This distribution may be more or less rigid and concerns an ideal and a high efficiency. Classical models of organization have a striking hierarchy feature, with defined roles and rigid compartment.

Currently, unchanging structure represented by organizations is not adapted to new requirements enterprises must fulfill. Butera highlights that this type of structure "remains essential for border demarcation between market and hierarchy, to maintain balance between strategy and structure to reallocate resources, but loses importance when it comes to defining the tasks and the manner of their address.

The review of the organization, reordering of roles and enrichment of missions of its component causes restructuring in order to get better efficacy. Today, from various reasons, many moves to restructure and change the organization can be seen, from which we can individualize the new organizational forms. Desreumaux (1996), Louart (1996), and Miles \& Snon (1992) have dealt with the concept NFO, highlighting specific characteristics (Table 1).

Table 1: The Specific Characteristics of New Organizational Forms

\begin{tabular}{|c|c|}
\hline & Groups of characteristics \\
\hline \multirow[t]{2}{*}{ I. } & General attributes \\
\hline & $\begin{array}{l}\text { Globalization } \\
\text { Hyper-flexibility, adaptability } \\
\text { Continuous improvement, innovation, } \\
\text { Orientation toward "stakeholders" } \\
\text { Tolerance to uncertainty }\end{array}$ \\
\hline \multirow[t]{2}{*}{ II. } & Structural features \\
\hline & $\begin{array}{ll}\text { Payment structure } & \begin{array}{l}\text { The absence of internal borders } \\
\text { Indistinctive external borders } \\
\text { Compatibility between the structure and work process }\end{array} \\
\begin{array}{l}\text { Decentralization } \\
\text { Network } \\
\text { Self-organization } \\
\text { Permeable borders }\end{array}\end{array}$ \\
\hline III. & Processing of information \\
\hline
\end{tabular}




\begin{tabular}{|l|l|}
\hline & $\begin{array}{l}\text { Integration of technology for telecommunications } \\
\text { Organization "electronics" }\end{array}$ \\
\hline IV. & Conception of jobs \\
\hline & $\begin{array}{l}\text { Empowering individuals and work groups (auto-control, entrepreneurship) } \\
\text { Continuous learning } \\
\text { Interoperable work, on team }\end{array}$ \\
\hline V. & Management \\
\hline & $\begin{array}{l}\text { Leadership without control: less directive and evaluation, more facilitation, } \\
\text { communication, work network } \\
\text { Tolerance to ambiguity, trust in individuals }\end{array}$ \\
\hline
\end{tabular}

Comet mentions all aspects of organizational changes over time, which allows supporting the transition from standing bureaucratic organization to procesual organization. She made several tables that illustrate the changes that have occurred in the division of labor, coordination mechanisms; change the systems of influence, the goals and values, environmental changes. To achieve the changes required by information and communication technologies, companies have adopted a vision through the process. Growing interest of companies for modeling processes may be referred by developing ERPs' and PGIs' (collaborative activity programs). Technological developments arising from the occurrences of Intranet, Internet determine enterprises to have a profound reconfiguration, often identified as a reconfiguration through the process or BPR.

Use of Intranet in the company trains changes in depth, both in the manner of work (rhytm, content of work, etc.) and organization. For example, management of "virtual" companies is allowed by the development of these technologies. New technologies of information and communication allow the radical organization and (put in question) phasing result in functional organization, which seems misfit to economic environment and technological developments. Hammer and Champy suggest replacing the cut function in the activities around an aggregation processes occurring in the enterprise. The vision of the enterprise, where it is considered an aggregation of processes enables an effective and efficient change of organization in relation to its internal and external environments. With the support of NTIC, a specific form of virtual enterprise is developed.

A new form of organization is now the network. Kiosur considers virtual organization as "an entity composed of members who perform the same work and communicate exclusively through electronics which suppress almost entirely physical meetings". Other authors refine their views, claiming that the organization may not be entirely virtual, this quality can be manifested at various levels: local, organizational or inter-organizational. Scouarec and Yanat distinguish two cases of establishment of network organizations:

- the cross crews consisted to achieve a specific mission in an organization; 
- grouping of separate entities to perform a certain task. This form of organization is opposed to functional enterprise, characterized by stiffness, especially in terms of reference of time and space. It shares mobile borders, is based and provides the appearance of new skills.

These changes do not remain without consequences on management models, because, besides the change the structure, organization-network cannot operate independently of a review of management powers.

\section{Human Resources Function: Evolution and Correlation with the Organization}

As enterprises are subjected to extensive changes, due to factors that influence their strategy and structure, their subsystems also, go through the same transformation. Since the 1980s, the human resources function has known a dynamic evolution, tending to decentralize, to reduce the vertical structure and to outsource tasks both inside and outside the enterprise. Literature study reveals some consistency between the configuration and policies of human resources management. Organizations with their structural configurations are complex entities, various and multiform, such as their relationships with human resource management are manifold.

In terms of developments that have known human resource management from the beginning of the $\mathrm{XX}^{\text {th }}$ century, Pichault (1996) offers a short, but interesting, history allowing specialists to form an overview of these changes, grouped into three stages:

- human resources management focused on personal activities, defined by Belanger and Petit (1998) as "all activities of attraction, development and conservation of human resources, aiming to provide to working structures a productive labor, stable and satisfied";

- systemic management of human resources, integrated gradually as a system in the enterprise. Human resources function interacts with other organizational variables to answer enterprise objectives and combine economic success with technical success and the social engineering; strategic management of human resources, through which function integrates to enterprise strategies and approaches to management.

This presentation captures well the transition from a human resource management which manages its own activities independent of any other variable (Phase I), then, secondly, the emerging needs to integrate this function with other organizational components to make the overall process more efficient. The integration process lasts long enough, because only in the 1980s the function has its place in the establishment, while the prerogative in enterprises was to restore performance and competitiveness objectives. 
Emerging of strategy notion inside the function and the fact that with the organizational strategy, an important role is also held by the strategies of the organization' players, train human resources management to a political management. Activities and practices of the function are widely redesigned under the influence of two phenomena:

- the development of new forms of organization, such as virtual enterprises and now network;

- a significant increase of use the new techniques of information and communication (NTIC) by enterprise staff.

The first cause of deep changes that faced and are facing human resource function is the organizational change of the enterprise, started by NTIC. Huault (1998) considers that new forms of organization lead to a redefinition of roles and functions within the enterprise, reducing the level and power of hierarchy but also the emergence of new setting and a profound evolution of human resources function.

The second cause of mutations that occurred in the functions of human resources is an increasing use of NTIC within the enterprise activities. Function must deal with complex mechanisms and have an immediate responsiveness to management earnings, forecast of the effectives and skills, in management of work time etc.

From this point of view, NTIC participate and support services of human resources and make the necessary changes in anticipation of structuring and proper functioning of the office. Study of Matmata, regarding the place of human resources function towards these changes, answer to the will of understanding and analyzing the impact that NTIC has on it.

It also responds to managers who want to know their effects in improving human resources performance in enterprise and the effectiveness of human resources function in its performance for operational structures.

Several research studies, but also the reality of today reveal that information technology will have a strong impact on the activities, location and direction of human resources, because it amends individual and collective work situations, but also operational processes of the channel. This way, significant changes in the channel value of enterprise take place. The academic thinking ranks human resources function mutations at the evolution of the work structures level, its missions that can be decentralized, outsourced or kept in the same service, but also to the level of each roles in reaching the specific objectives etc.

Henriet (1999) considers that human resources function has gained new features which may be formulated as follows: 
- a new configuration, characterized by decentralization and reduction of hierarchy, mainly to increase its reactivity;

- a new strategic dimension, taken to obtain a competitive advantage by refocusing on the issue of competencies and outsourcing of activities not covered in this new feature of function;

- new powers in the human resources function.

Human resources function is in full transformation, characterized by processes of dispersal and delegation. The first process involved a large movement of decentralization and reduction of central services, simultaneously with research responsibility of actors closer to the field.

The second process was possible because of NTICs' influences, which authorized the emergence of an initial redistribution of the function, increasingly decentralized at the operational level, sometimes even relocated outside the organization borders.

Today enterprises are refocused on their base occupation and outsource some of the functional and administrative areas considered non-strategic. This follows a redeployment of forces and their professional resources to new roles, with lower costs and with high added value. As outsourced activities we can mention payment, selection of candidates (recruiting), training.

\section{Organizational Change and Human Resource Management}

New organizational forms that have appeared in the enterprise do not remain without consequences in terms of issues facing human resource management specialists in their role and mission, but also the structure and position functions as such. These developments do not have a radical character, since this is more than a change in the context of action faced to the organizational changes. Many researchers urge caution regarding the influence of organizational structure movements on human resources management, considering the differences between what is said and what is actually done in the enterprises. It remains essential that between the organizational structure and human resource management there must be a compatibility, to provide the good functioning of the enterprise.

Interesting, are form this viewpoint, the proposals of Nizet and Pichault (1996) which based on the five structural configurations of Mintzberg (2004) identify five basic models of human resource management: arbitrary, objective, individualized, conventionalist and valuable. These models are, according to two researchers, dependent variables from structural configurations (Table 2). 
Table 2: Correlations between Structural Configurations, the Dominant Factors and Models of Human Resource Management

\begin{tabular}{|l|l|l|l|}
\hline $\begin{array}{l}\text { No } \\
1\end{array}$ & $\begin{array}{l}\text { Structural } \\
\text { configuration }\end{array}$ & Dominant actors & $\begin{array}{l}\text { Models of human resources } \\
\text { management }\end{array}$ \\
\hline 1 & Entrepreneurial & Strategic management & Arbitrary \\
\hline 2 & Bureaucratic & $\begin{array}{l}\text { Specialists from techno- } \\
\text { structure }\end{array}$ & Objective \\
\hline 3 & Professional & Qualified operators & Conventionalist \\
\hline 4 & Missionary & $\begin{array}{l}\text { Without an officially } \\
\text { designated actor }\end{array}$ & Valuable \\
\hline 5 & Adhocratic & Qualified operators & $\begin{array}{l}\text { Based on an individual/ hierarchical } \\
\text { line }\end{array}$ \\
\hline
\end{tabular}

The study of compatibility between organizational structures and human resource management was the object of several debates in the trade journals. Henriet (1999) tries to provide an answer concerning the implications that organizational transformations have on human resource management policies, but also on how human resources policies participate in making these changes. Human resources policies play a key role in facilitating the development of new cultures and successful launch of the new technologies of information and communication, being active elements in the process of change. Interactions between organizational changes and introduction of NTIC, in which human resource policies are active elements of change, are induced in the Figure 1.

Figure 1: Interactions between Organizational Changes and Introduction of NTIC

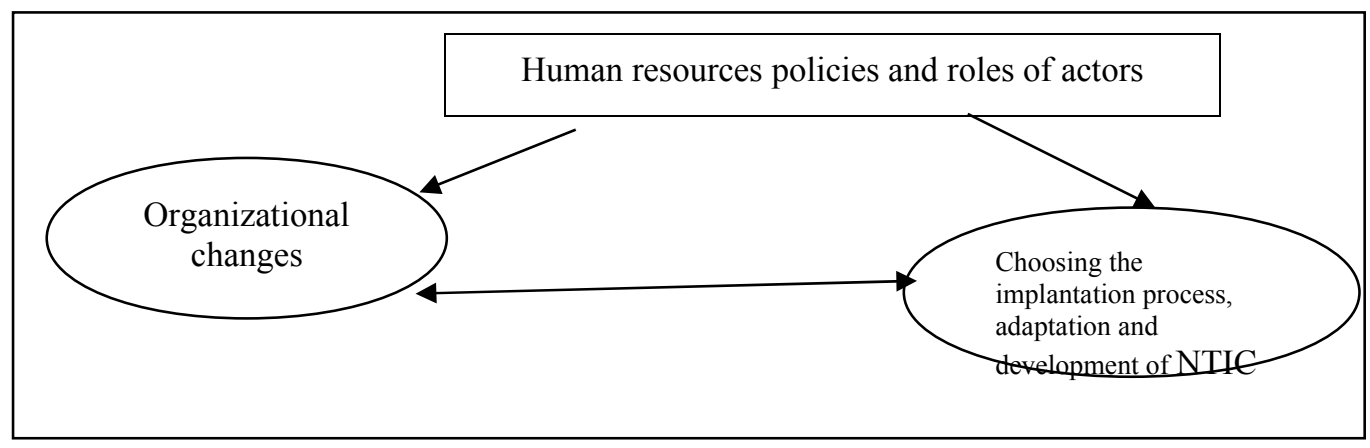


Because of their role and position, human resources and organization actors are in the center of change, especially those caused by NTIC. From another perspective, it is possible that some changes motivated by different factors to claim NTICs' development. The role of human resources is fundamental here, considering the choices they must make in accordance with the organizations' objectives.

Louart (1996) considers that besides the impact of NTIC, human resource management depends on many factors:

- organizational contexts, especially the internal structures and their environments;

- the actors point out in the company, with their influences of power that they own;

- uncertainties about the desire that these actors work together.

It is clear that human resource management changes depending on organizational developments, being consequential in the heart of change, but also their catalyst. The same is sustained by Chambrier, who noted that under the influence of organizational developments human resource management changes and realize change. "The relationship between human resource management (MRU) and organization in the new organizational forms (NFO) are placed to the exigency level of a direct participation of human resources in new practices of work...passing from the logic of minimizing the influence of human variables on systems performance to a logics that seeks to integrate human variables to relentlessly improve enterprise performances".

Regarding the involvement of human resources function in technological changing, its organizational structure is most appropriate in assessing the interaction between technology and work organization. It is able to provide organizational and human constraints to support the introduction of new technologies, to judge organizational changes to be made to make suitable structures to facilitate optimal use of NTIC. Human resources direction is also the one who should construct appropriate training programs and foster a culture of continuous learning, Jacob and Ducharme conclude that the essential of such approach is to adapt to the context of single organizations and function and that there is no other form of success.

Regarding the position that the human resource function will have to take in the technological change, the two authors mention that the treasurer should adopt in this case the anthropocentric paradigm, because the development and use of knowledge are applicable to each individual. 


\section{Conclusion}

Organizational changes may be characterized as a constant which is part of company life. They are described in a partial or general manner by many theorists. The paper points out that change in the organization and those of human resource functions overlap interact with each other, hence the need for compatibility between the two assemblies.

The first part takes major changes mentioned in the literature about the structural configuration of enterprises, especially those of H. Mintzberg (1993) and Porter and Millar (1985), then leap from the traditional organization to the new organizational forms (virtual enterprise, network) on the spur of NTIC. The analysis evolution of the enterprise is extended to the human resources function level, considered as an organization within the overall organization, and which is subjected to the same restraints. This study wants to remove any technological determinism, giving an important job to organizational actors, who ensure the successful choice of organizational variations. It does not mean that it negates any effect of NTIC on the choice of organizational models to the human resources functions level, considered as an organization within the overall organization, and which is subjected to the same restraints.

Developments in human resource function are presented in the second part, where the impact of using NTIC is examined, but also the double movement of decentralization. Human resources have a catalyst role in the organizational change and the introduction of NTIC. Louart (1995) considers that besides NTIC, human resources function depends on a similar number of factors.

In NFO, human resource management plays a central role in involving and enriching its culture management, in the strategic process, in structure, but also in human capital management, in enriching and improving human behavior, motivation and autonomy.

\section{References}

Belanger, L. and Petit, A. (1998), Gestion stratégique et operationelle des ressources humaines, Bourcherville, Gaëtan Morin, p.5.

Besseyre des Horts C.H. (1987), «Typlologies des pratiques de gestion des ressources humaines», Revue Française de Gestion, No. 65-66, Novembre-Décembre.

Desreumax, A. (1996), «Nouvelles formes d'organisations et evolution de l'entreprise», Revue Francaise de Gestion, No.107, Paris, Janvier-Février.

Gazier, B. (1993), Les strategies des ressources humaines, Paris, La Découverte.

Henriet, B., (1999), «La gestion des resources humaines face aux transformations organisationelles», Revue Francaise de Gestion, Juin-Jouillet-Août, Paris. 
Huault, I. (1998), "Les nouvelles dimensions du management. La gestion des resources humaines dans les nouvelles organisations», Cahiers Francais, Management et Organization des Enterprises, no. 287.

Louart, P. (1995), Succès de l'Intervention en Gestion des Ressources Humaines, RueilMalmaison, Editions Liaisons.s

Louart, P. (1996), «L'apparente revolution des formes organisationnelles», Revue Francaise de Gestion, no.107, Janvier-Février.

Milles, R.E. and Snow, C.C. (1992), "Causes of failure in networks organisations", California Management Review, Los Angeles.

Mintzberg, H., (1993), Structure in fives: Designed Effective Organisations, Prentice Hall, London.

Mintzberg, H. (2004), Le management. Voyage au centre des organisations, Les Editions d'Organisation, Paris/Montréal.

Peretti, J.M. (1999), Dictionnaire des resources humaines, Paris, Vuibert.

Pichault, F. (1996), Ressources humaines et changement stratégique. Vers un management politique, De Boeck Université, Montréal.

Porter, M. and Millar, V. (1985), "How information gives you competitive advantage", Harvard Business Review, Vol. 63, no. 4.

Roux, D. and Soulier, D. (1997), Nouvelles technologies de l'information et gestion de l'entreprise, in Encyclopedie de Gestion, Economica, Paris. 